\title{
Merak Port Customer Loyalty
}

Sohwa Rizkia Rizal ${ }^{1}$

${ }^{1}$ Faculty of Economic-Universitas Negeri Jakarta-Indonesia

Agung Kresnamurti Rivai ${ }^{2}$, Rahmi $^{3}$

${ }^{2}$ Faculty of Economic-Universitas Negeri Jakarta-Indonesia

${ }^{3}$ Faculty of Economic-Universitas Negeri Jakarta-Indonesia

Correspondence: sohwarizkia@gmail.com

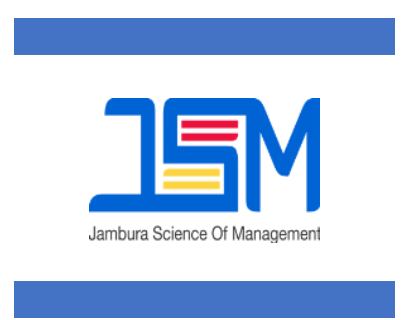

JSM

Volume 4

Number 1

January 2022.

Received on27 July 2021

Revised on 21 Sept. 2021

Accepted on 30 Sept 2021

The journal allows the authors to hold the copyright without restrictions and allow the authors to retain publishing rights without restrictions. Authors retain copyright and grant the journal right of first publication with the work simultaneously licensed under a creative commons attribution 4.0 international license.

\section{(c) (1)}

DOI: 10.37479

\section{ABSTRACT}

Purpose: The aim of this research was to examine the direct impact of service quality, trust and customer satisfaction variables on customer loyalty. As well as the indirect effect between service quality and customer satisfaction on customer loyalty through trust variable.

Design/Methodology/Approarch: This research uses a quantitative approach and data collected using survey with questionnaire as an instrument. The sample of this research are 200 Merak Port customers, that have visited Merak Port at least two times in the past year and have visited Merak Port before and after 2019. The data analysis technique uses SPSS version 22 LISREL 8.8 to analyze and process research data.

Findings: The hypothesis finding show that only the customer satisfaction variable positively and significantly affect customer loyalty. The trust variable as a mediator in the relationship between service quality and customer satisfaction on customer loyalty shows insignificant results.

Keywords: Service Quality; Trust; Customer Satisfaction; Customer Loyalty; Merak Port

\section{INTRODUCTION}

Indonesia is the largest archipelagic and maritime country with 16.056 island spread throughout its territory. As an archipelagic country, Indonesia needs transportation facilities to support the process of moving people and goods from one region to another. Ports as a means of supporting sea transportation need to be managed efficiently, but according to The Global Competitiveness Report 2019, Indonesia's port efficiency is still in ranked 61 out of 141 countries surveyed (Subdirektorat Statistik Transportasi, 2019). Merak Port is one of the ports in Indonesia managed by PT ASDP Indonesia Ferry which plays a vital role. Merak Port is a sea port located in Cilegon City Banten, which serves crossings between Java Island and Sumatra Island. According to Intari et al. (2019) Merak Port is a public port that is 
very vital in driving the wheels of the Indonesian economy. Activities in Merak Port including passenger crossing services and loading and unloading of goods.

Merak Port is the largest port service provider serving the Java to Sumatra route, in fact the government has provided another route, namely the Sea Highway crossing route that connects Tanjung Priok - Lampung Panjang Port. However, this route is considered to be very new, the number of ships serving the crossing is still limited and the fares are also more expensive than the Merak Port, so passengers are "forced" to be loyal to the Merak Port service provider. On this basis, customers tend to have fake loyalty levels, caused by the lack of alternatives. However, even so, due to the lack of attitudinal preferences owned by customers, customers still have a tendency to switch to other service providers or other modes of transportation. For this reason, the factors that affect their loyalty need to be assessed and studied properly (Sun \& Duan, 2019). Fake loyalty will make customers feel loyal when they are not, when they start to be free to make decisions, they will act like ordinary consumers in a free competitive market. They will be truly loyal when they are satisfied. For this reason, researchers feel it is important to carry out research on the antecedents of loyalty to Merak Port. According to Oliver (1999) Loyalty has become a cornerstone for a firm to gain a competitive success. It's cheaper to keep an existing customer rather than to gain new customer. Moreover, loyalty create resistance in consumers to potential competitor offers (Servera-francés et al., 2019). Even though it has a vital role, there are still many problems that happen in Merak Port.

There is often accumulation of vehicles and congestion, which causes vehicles to snake out of the port. On Thursday, December 242020 there was a traffic jam extending to Cikuasa Atas Street caused by the ticket barcode system at Merak Port had stopped operating (Yandhi, 2020). Merak Port officers who are often negligent in serving passengers. On October 16, 2020, an elderly passenger died due to falling from a pedestrian bridge (gang way) at Pier 3 of Merak Port, this is closely related to the ramp door officers didn't provide assistance to the elderly passenger (Toiskandar, 2020). The executive pier of Merak Port which is assessed by the Masyarakat Transportasi Indonesia (MTI) does not meet the executive requirements, this is happen because the service of executive pier, the ship qualification and ship sailing time are not considered to meet executive requirement.

Service quality given by service provider is the criteria that considered by customer to make the decision which service provider they want to choose. One of the determinant of customer loyalty is a consistent delivery of quality. Parasuraman et al. (1988) said that quality of service is distinction between what customer expect for the services and customer perception for the real service. Kesper et al. (1999) define service quality as how far the service offered can meet the

P-ISSN: 2655-3651 E-ISSN: 2656-0435 $\quad$ P a g e | 11 
customer expectancy. Quality of service is one of the important dimension which head to customer loyalty (Chang \& Thai, 2016; Yacob et al., 2016), and this several problem of Merak Port service quality have the opportunity to impact the degree of customer loyalty. Previous study discovered service quality has a significant effect on customer loyalty (Haryanti and Susila, 2019; Omoregie et al., 2019; Prabumenang et al., 2020).

Acts of thuggery also often occur in the environment around Merak Port, acts of thuggery included robberies and brokers, have happened for years. However, this is still happening until now. Several comments on PT ASDP Indonesia Ferry's social media accounts, said that that customers often find brokers, being asked for more money by thugs and pickpockets. This situation can cause and increase customer uncertainty with the reliability of Merak Port. According to Morgan and Hunt in darmawan (2018) trust will exist if the customer has a confidence to engange in a relationship with credible party. Garbarino and Johnson (1999) said trust is customer beliefs in the reliability and the quality of the service that given by the company. This lack of security, can affect costumer trust, and many complaints about Merak Port services, illustrates customer dissatisfaction with Merak Port. Several studies found that trust positively and significantly affect customer loyalty (Omoregie et al., 2019; Prabumenang et al., 2020; Rizan et al., 2016). Moreover, several previous studies found that customer trust mediating the service quality and customer satisfaction on customer loyalty (Minrohayati et al., 2017; Carranza et al., 2018; Haron et al., 2020; Saputra et al., 2020).

In the past studies customer satisfaction act as a key driver of customer loyalty. Customer satisfaction is the pleasure or displeasure someone has as a result of comparing the perceived performance (or outcome) of a service to expectancy. If the performance or experience falls short of the customer's expectations, the customer is dissatisfied. Customer is satisfied if it meets their expectations. According to Dagger and O'Brien customer satisfaction is one of the major factor for business organizations to develop a long term relationship with customer. This finding also supported by previous studies which claim customer satisfaction positively and significantly affect customer loyalty (Rocío Carranza et al., 2018; Kotler \& Keller, 2016; Omoregie et al., 2019; Saputra et al., 2020; Yacob et al., 2016).

\section{METHODS}

This study using quantitative methods to answer the hypotheses proposed. The study design is descriptive and causal (Malhotra, 2010). This study population consist of Merak Port Customer. The population is Merak Port service user and using infinite population. This study sample consist of customer of Merak Port who visited Merak Port minimum twice for the last one year, and had visited Merak Port before and after 2019. Two hundred Merak Port 
participated (Hair et al., 2013). Data collection is from online and offline survey, Google Form was used for online survey. The measurement used five point likert scale from 1 (Strongly disagree) to 5 (Strongly Agree). The validity test using Pearson Product Moment Correlation with 5\% significance and the $\mathrm{r}$ table value is 0,138 . The reliability test using Cronbach Alpha, it is appearing to be $>0.60$ with SPSS 22. The SEM analysis using LISREL 8.8.

\section{Variable Research and Operational Definitions}

The variables in this study are:

1) Customer Loyalty $(Z)$

Loyalty is a "a deeply held commitment to rebuy or repatronize a preferred product or service in the future despite situational influences and marketing efforts having the potential to cause switching behavior." (Kotler \& Keller, 2016). According to Jones and Taylor loyalty can be measure with three dimensions, namely

(i) Behavioural loyalty, (ii) Attitudinal Loyalty and (iii) Cognitive Loyalty (Rizan et al., 2016).

2) Customer Trust (Y)

Trust come is customer beliefs in the reliability and quality of the service that given by the company (Isaeva et al., 2020). According to Morgan and Hunt there are three dimension to measure customer trust, namely (i) capabilities (ability, (ii) goodness (benevolence) and integrity (Rizan et al., 2016).

3) Service Quality (X1)

Service of Quality is distinction between what customer expect for the services and customer perception for the real service. Previous studies measuring the quality of service using SERVQUAL measurement model by Parasuraman et al. (1988), therefore researcher also using SERVQUAL measurement model. Service quality model be expanded by Parasuraman (1988) are (i) Tangibility, (ii) Reliability, (iii) Responsiveness, (iv) Assurance, and (v) Empathy (Boonlertvanich, 2019; Murali et al., 2016; Yacob et al., 2016).

4) Customer Satisfaction (X2)

Customer satisfaction is the pleasure or displeasure someone has as a result of comparing the perceived performance (or outcome) of a service to expectancy. If the performance or experience falls short of the customer's expectations, the customer is dissatisfied. Customer is satisfied if it meets their expectations. There are two dimensions of customer Satisfaction namely, expectation and performance (Kotler \& Keller, 2016). 


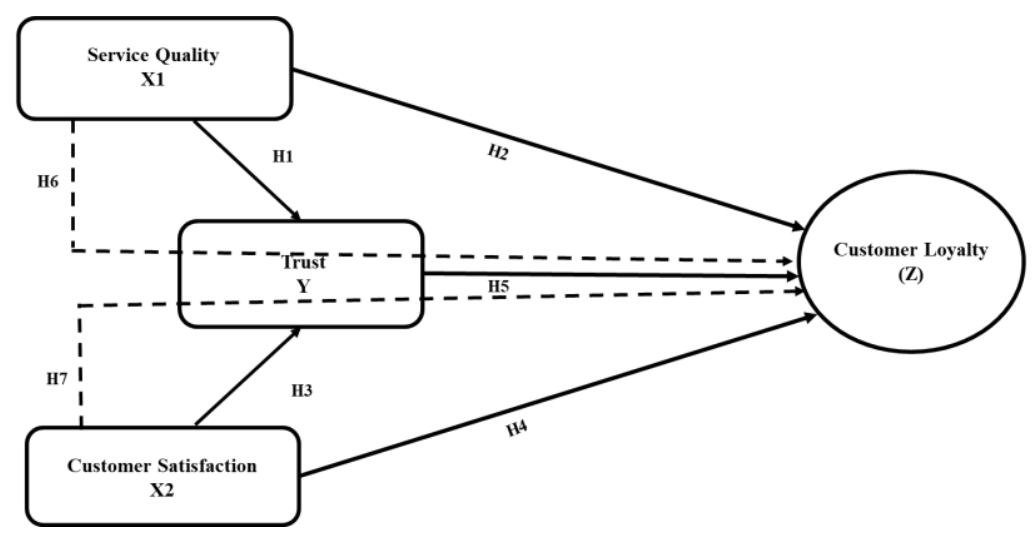

Figure 1. Research Model

Source: Data processed by researchers (2021)

\section{Hypothesis}

H1 : Service quality affect trust.

H2 : Service quality affect customer loyalty.

H3 : Customer satisfaction affect trust.

H4 : Customer Satisfaction affect customer loyalty.

H5 : Trust affect customer loyalty.

H6 : Trust mediates the relationship between service quality and loyalty.

H7 : Trust mediates the relationship between customer satisfaction and loyalty.

\section{RESULTS}

\section{Profile of Respondents}

The sample for this study are 200 respondents. Table 1 (See Table 1) inform the detail of respondents' descriptive analysis. In general, the majority of respondent were dominated by respondent who used private transportation, with a percentage of approximately $72 \%$ of total respondent, the majority of respondents were dominated by man, with a percentage of approximately $60 \%$ respondent, the majority of respondent were dominated by respondent whose age 21-25 years' old, with a percentage of approximately $35 \%$ of total respondent, the majority of respondent were dominated employee, with a percentage $37 \%$ of total respondent, the majority of respondent were dominated by respondent whose income Rp2.500.001, -Rp5.000.000,--

Table 1. Profile of Respondents

\begin{tabular}{lccc}
\hline No & Categorical & Frequency & Percentage \\
\hline 1 & & Transportation & \\
\hline & Private & 144 & $72 \%$ \\
& Public & 56 & $28 \%$ \\
\hline 2 & & Gender &
\end{tabular}




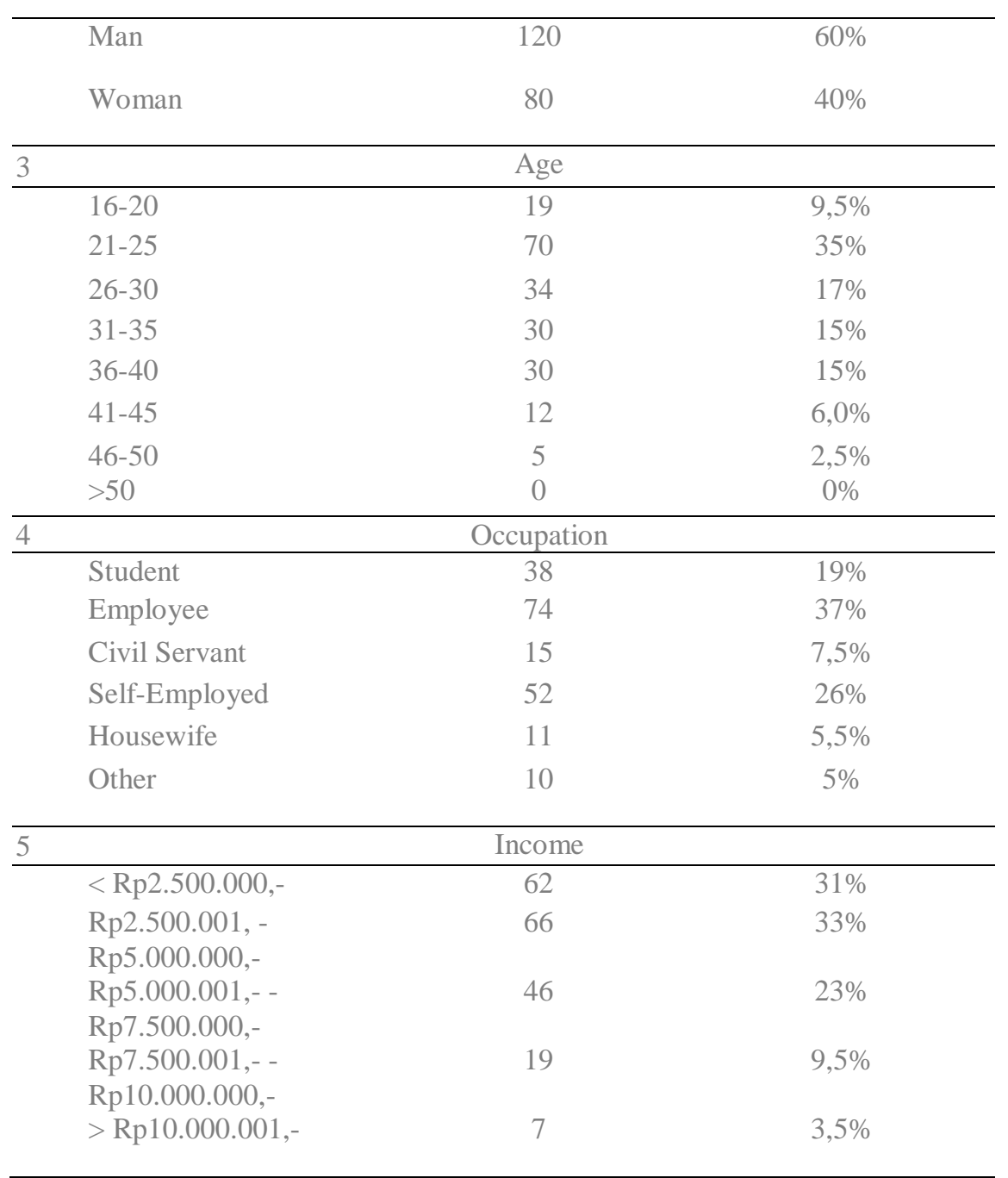

Source: Data processed by researchers (2021)

\section{Validity Test}

The validity test shows the level of accuracy between the data that actually occurs on the object and the data obtained and reported by the researcher (Sugiyono, 2019). This study using Pearson Moment Correlation for Validity Test. Values are valid if the $r$ value is bigger than the $r$ table. The $r$ table for significance of 5\% and the number of samples two hundred is 0.1388 . The validity test result can be shown in the following table:

Table 2. Validity Test Results

\begin{tabular}{lcccc}
\hline Variable & Indicator & $\begin{array}{c}\mathbf{R} \\
\text { value }\end{array}$ & r table 5\% & Information \\
\hline & SQ1 & 0,626 & & Valid \\
& SQ2 & 0,616 & & Valid \\
Service & SQ3 & 0,632 & & Valid \\
Quality & SQ4 & 0,609 & 0,1388 & Valid \\
(X1) & SQ5 & 0,753 & & Valid \\
& SQ6 & 0,673 & & Valid \\
& SQ7 & 0,616 & & Valid \\
& SQ8 & 0,622 & & Valid \\
& SQ9 & 0,686 & 0,1388 & Valid
\end{tabular}




\begin{tabular}{|c|c|c|c|c|}
\hline & SQ10 & \multicolumn{2}{|l|}{0,676} & Valid \\
\hline & SQ11 & \multicolumn{2}{|l|}{0,651} & Valid \\
\hline & SQ12 & \multicolumn{2}{|l|}{0,619} & Valid \\
\hline & SQ13 & \multicolumn{2}{|l|}{0,633} & Valid \\
\hline & SQ14 & \multicolumn{2}{|l|}{0,630} & Valid \\
\hline & SQ15 & \multicolumn{2}{|l|}{0,696} & Valid \\
\hline & SQ.16 & \multicolumn{2}{|l|}{0,679} & Valid \\
\hline \multirow{5}{*}{$\begin{array}{l}\text { Customer } \\
\text { Satisfactio } \\
n(\mathrm{X} 2)\end{array}$} & CS1 & 0,808 & \multirow{5}{*}{0,1388} & Valid \\
\hline & $\mathrm{CS} 2$ & 0,823 & & Valid \\
\hline & $\mathrm{CS} 3$ & 0,719 & & Valid \\
\hline & CS4 & 0,827 & & Valid \\
\hline & CS5 & 0,751 & & Valid \\
\hline \multirow{10}{*}{ Trust (Y) } & T1 & 0,711 & \multirow{10}{*}{0,1388} & Valid \\
\hline & $\mathrm{T} 2$ & 0,704 & & Valid \\
\hline & T3 & 0,773 & & Valid \\
\hline & $\mathrm{T} 4$ & 0,766 & & Valid \\
\hline & T5 & 0,770 & & Valid \\
\hline & T6 & 0,660 & & Valid \\
\hline & $\mathrm{T} 7$ & 0,701 & & Valid \\
\hline & $\mathrm{T} 8$ & 0,654 & & Valid \\
\hline & T9 & 0,715 & & Valid \\
\hline & $\mathrm{T} 10$ & 0,704 & & Valid \\
\hline \multirow{6}{*}{$\begin{array}{l}\text { Customer } \\
\text { Loyalty (Z) }\end{array}$} & CL1 & 0,640 & \multirow{6}{*}{0,1388} & Valid \\
\hline & CL2 & 0,617 & & Valid \\
\hline & CL3 & 0,670 & & Valid \\
\hline & CL4 & 0,760 & & Valid \\
\hline & CL5 & 0,624 & & Valid \\
\hline & CL6 & 0,659 & & Valid \\
\hline
\end{tabular}

Source: Data processed by researchers (2021)

The results of validity test data in the table 2 shows that all indicator are bigger than 0,1388 so that all the indicator are valid because the $r$ values are bigger than the $r$ table.

\section{Reliability Test}

Reliable is related with the level of data consistency at the certain time intervals (Sugiyono, 2019). This study using Cronbach's Alpha for reliability test, and Cronbach's Alpha method for measuring reliability ranges from 0 to 1 , with a value of 0.60 to 0.70 considered the lower limit of acceptability (Hair et al., 2013). The reliability test result can be shown in the following table:

Table 3. Reliability Test Results

\begin{tabular}{lcc}
\hline \multicolumn{1}{c}{ Variable } & Cronbach's Alpha & Information \\
\hline Service Quality & 0,908 & Reliable \\
Customer Satisfaction & 0,785 & Reliable \\
Trust & 0,893 & Reliable \\
Customer Loyalty & 0,736 & Reliable \\
\hline
\end{tabular}

Source: Data processed by researchers (2021)

The reliability test results show that all indicators are reliable because the Cronbach's Alpha values are bigger than 0.7. 


\section{Confirmatory Factor Analysis}

CFA was conducted to see if the indicators and dimensions forming the latent construct were valid indicators and dimensions as a measure of the latent construct (Haryono, 2016). Researchers use first order construct on LISREL 8.8.

1) Service Quality

Service quality variable has sixteen indicators. Indicator of service quality variable was decreased to 14 indicators after processing the model in the first order construct. Test findings show, service quality variable model generates a good level of acceptance at this point. Outcome of testing service quality, GFI 0,91; RMSEA 0,064; RMR 0,033; CMIN/DF 1,82; AGFI 0,88; TLI/NNFI 0,97; CFI 0,98.

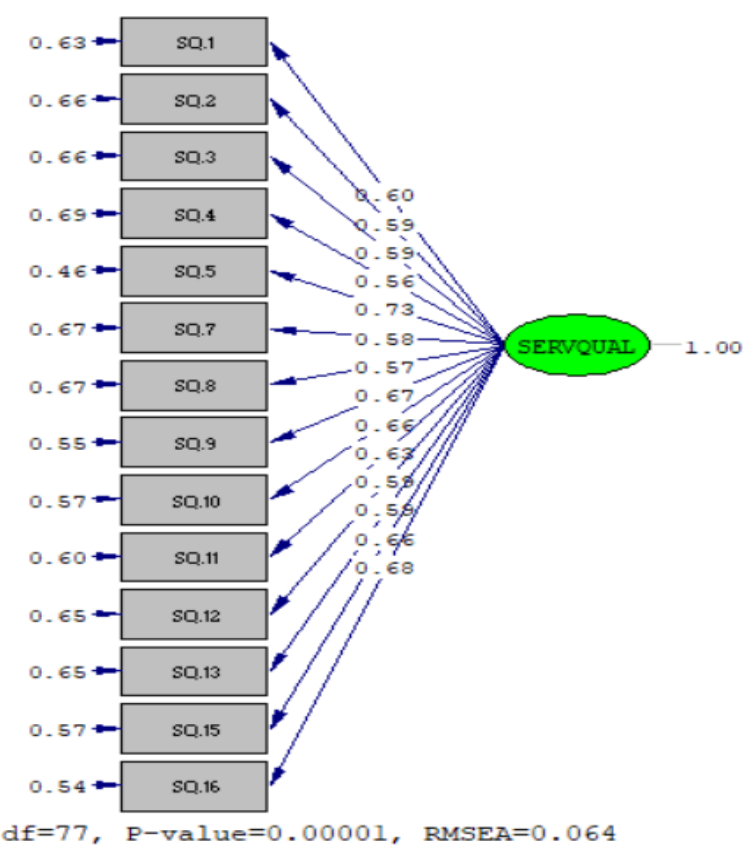

Figure 2. Service Quality First Order Construct Model (Source: Data processed by researchers, 2021)

2) Customer Satisfaction

Customer satisfaction variable consist of five indicators. There are no wasted indicators after the model has been processed in the first-order construct. Test outcome indicate that customer satisfaction variable model produces the good level of acceptance at this point. Results of testing customer satisfaction consist of GFI 0,97; RMSEA 0,14; RMR 0,02; CMIN/DF 5,1; AGFI 0,85; TLI/NNFI 0,93; CFI 0,97. 


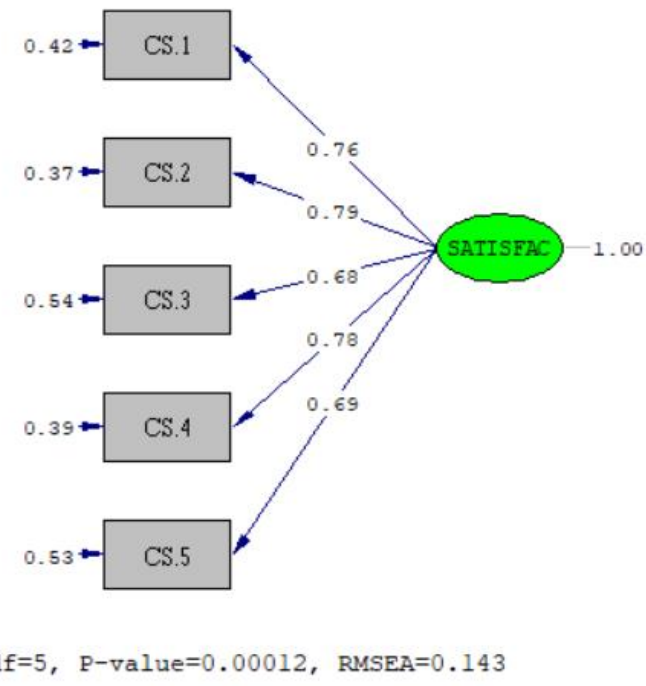

Figure 3. Customer Satisfaction First Order Construct Model (Source: Data processed by researchers, 2021)

3) Customer Trust

Trust variable has ten indicators. There are no wasted indicators after the model has been processed in the first-order construct. At this point, test results show trust variable model generates good acceptability level. Results of testing trust consist of GFI 0,92; RMSEA 0,08; RMR 0,049; CMIN/DF 2,4; AGFI 0,88; TLI/NNFI 0,97; CFI 0,98.

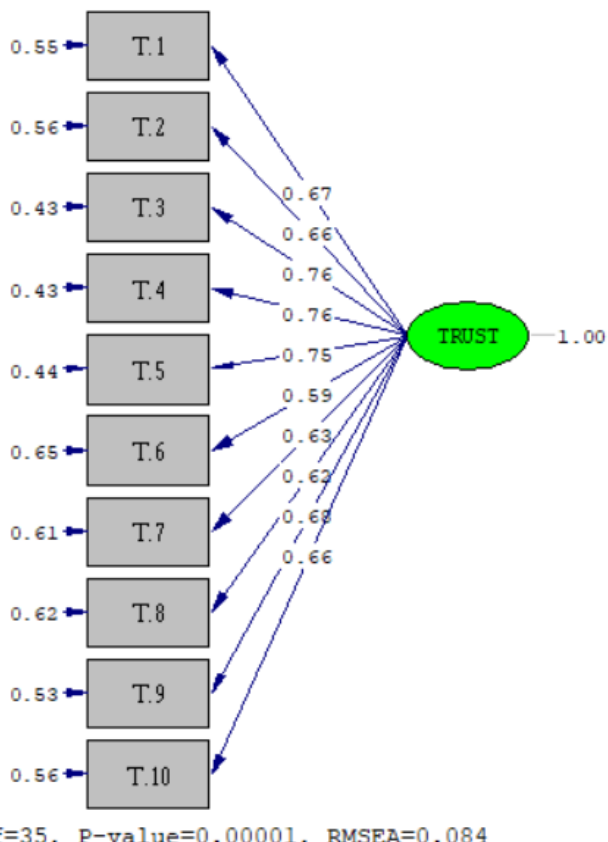

Figure 4. Trust First Order Construct Model (Source: Data processed by researchers, 2021) 
4) Customer Loyalty

Customer loyalty variable has six indicators. Indicator of customer loyalty variable was decreased to 4 indicators after processing the model in the first order construct. Test results show customer loyalty variable model produces better acceptability level at this point. Results of testing customer loyalty consist of GFI 1,00; RMSEA 0,0; RMR 0,01; CMIN/DF 0,86; AGFI 0,98; TLI/NNFI 1,00; CFI 1,00.

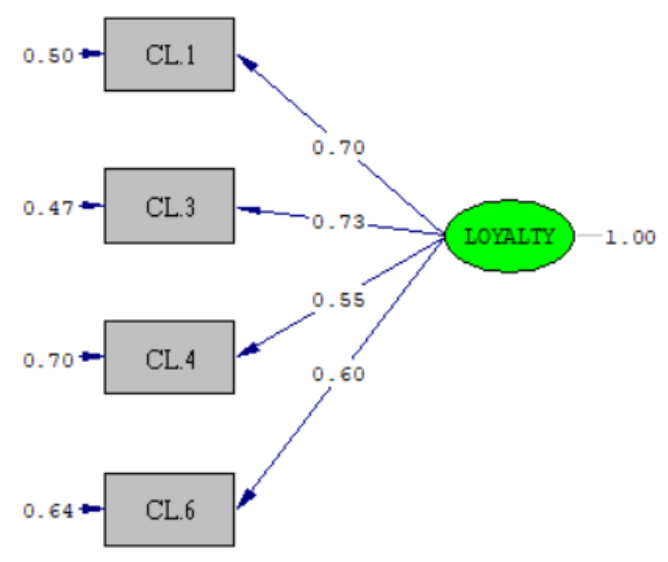

Chi-Square $=1.72, \mathrm{df}=2, \mathrm{P}$-value $=0.42244, \mathrm{RMSEA}=0.000$

Figure 5. Customer Loyalty First Order Construct Model (Source:

Data processed by researchers, 2021)

\section{Full Model SEM}

The purpose of the full model SEM is to find out and analyze the relationship between one variable to another. The result of the Full Model SEM of this study can be shown in this following picture and table:

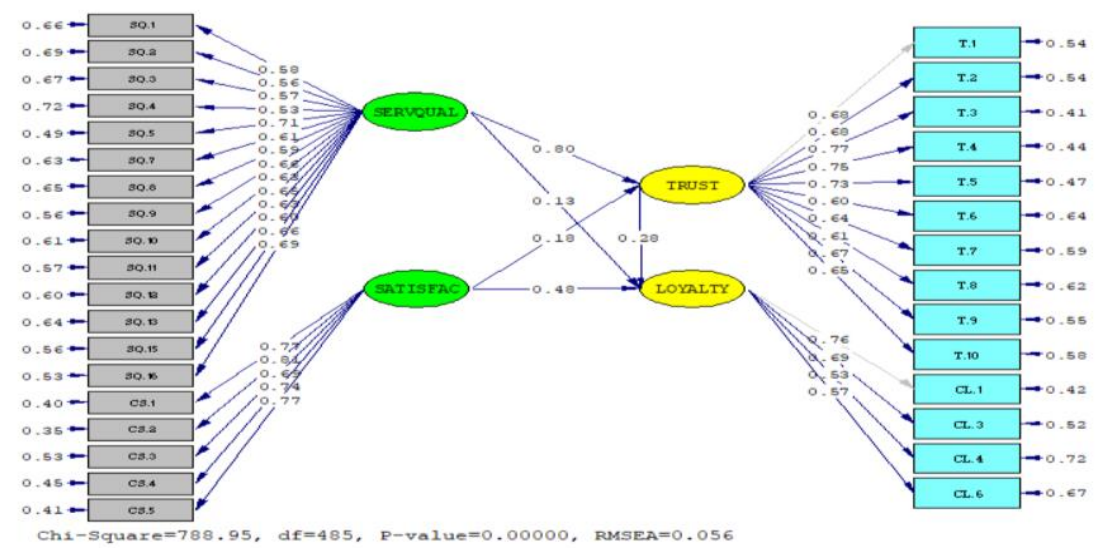

Figure 6. Full Model SEM (Source: Data processed by researchers, 2021) 
Table 4. Full Model SEM

\begin{tabular}{lccc}
\hline $\begin{array}{c}\text { Goodness of Fit } \\
\text { Indices }\end{array}$ & Cut of Value & Hasil & Evaluasi Model \\
\hline GFI & $\geq 0,90$ & 0,81 & Close Fit \\
RMSEA & $\leq 0.08$ & 0,056 & Good Fit \\
RMR & $\leq 0.05$ & 0,037 & Good Fit \\
CMIN/DF & $\leq 2.00$ & 1,62 & Good Fit \\
AGFI & $\geq 0.90$ & 0,78 & Close fit \\
TLI/NNFI & $\geq 0.90$ & 0,98 & Good Fit \\
CFI & $\geq 0.95$ & 0,98 & Good Fit \\
\hline \multicolumn{4}{r}{ Source: Data processed by researchers (2021) }
\end{tabular}

The result from Figure 6 and Table 4 shows that the full model in this study has met the requirement and can be said to be fit, because the value is mostly bigger than cut of value, therefore we were assured that the path diagram for the research model was an adequate representation of the entire set of causal relationships.

\section{Hypothesis Test Results}

Structural equation model is needed to test the data whether the hypothesis is accepted or not. Hypothesis test using multivariate SEM with LISREL 8.8 version. Hypothesis testing is carried out using tvalue with a significance level of 0.05 . If the $t$-value $>1.96$ or the probability value $(\mathrm{P}) \leq 0.05$, then $\mathrm{H} 0$ is rejected (the research hypothesis is accepted) (Haryono, 2016).

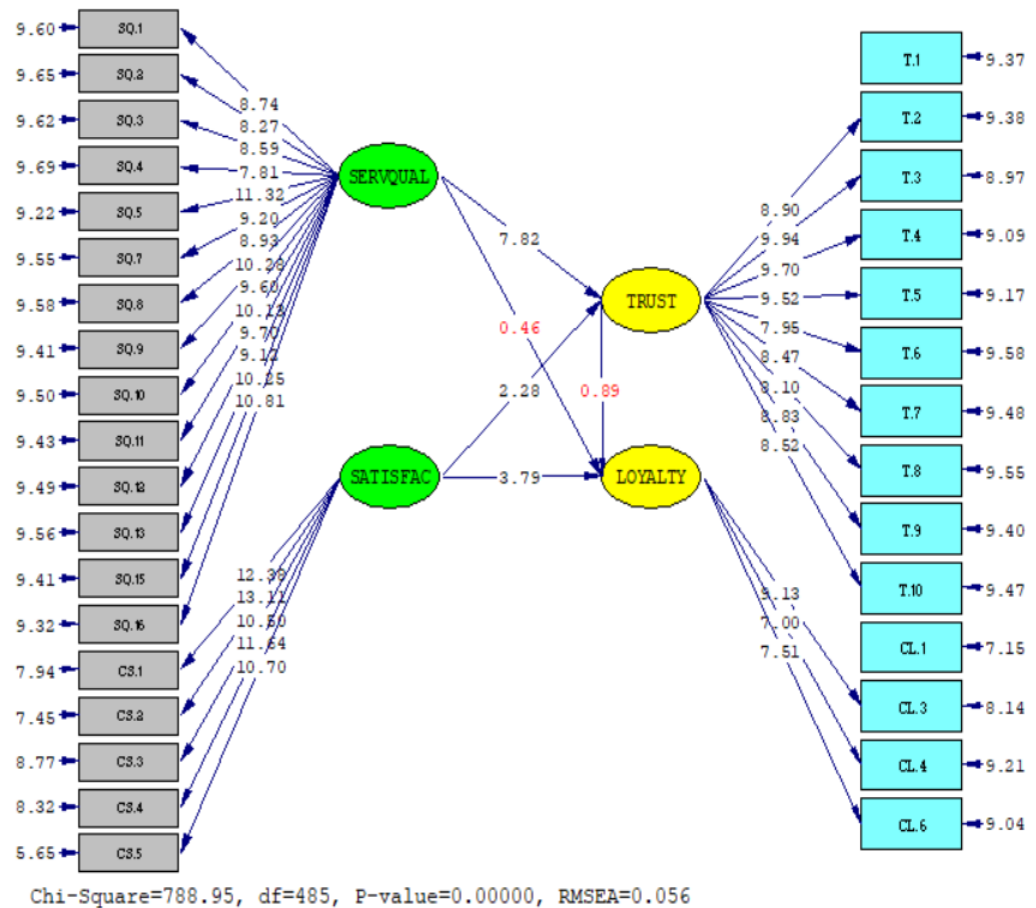

Figure 7. Structure Equation Model Results (Source: Data processed by researchers, 2021) 
Table 5. Structure Equation Model Results

\begin{tabular}{|c|c|c|c|c|c|c|}
\hline $\mathrm{H}$ & Independent Variable & & Dependent Variable & $\begin{array}{c}\text { Standard } \\
\text { ized Total } \\
\text { Effect }\end{array}$ & $\begin{array}{c}T- \\
\text { Values }\end{array}$ & Interpretation \\
\hline$\overline{\mathrm{H} 1}$ & Service Quality & & Trust & 0,80 & 7,82 & Positive Significant \\
\hline $\mathrm{H} 2$ & Service Quality & & Customer Loyalty & 0,13 & 0,46 & Not Significant \\
\hline $\mathrm{H} 3$ & Customer Satisfaction & & Trust & 0,18 & 2,28 & Positive Significant \\
\hline $\mathrm{H} 4$ & Customer Satisfaction & & Customer Loyalty & 0,48 & 3,79 & Positive Significant \\
\hline H5 & Trust & & Customer Loyalty & 0,28 & 0,89 & Not Significant \\
\hline H6 & Service Quality & Trust & Customer Loyalty & 0,22 & 0,89 & Not Significant \\
\hline $\mathrm{H} 7$ & Customer Satisfaction & Trust & Customer Loyalty & 0,05 & 0,86 & Not Significant \\
\hline
\end{tabular}

Source: Data processed by researchers (2021)

The hypothesis test is significant if the t-value is $>1,96$. Research result presented in the table 5 indicate that service quality affect customer trust with t-value 7,86 >1,96. The service quality does not affect customer loyalty because the $\mathrm{t}$ value is $0,46<1,96$. The customer satisfaction affect customer trust 2,28 $>1,96$. The customer satisfaction affect customer loyalty $3,79>1,96$. The customer trust does not affect customer loyalty because the $t$ value $0,89<1,96$. The service quality does not affect customer loyalty through customer trust because the $t$ value is $0,89>1,96$. The customer satisfaction does not affect customer loyalty through customer trust because the $t$ value is $0,86>1,96$.

\section{Direct and Indirect Effect}

Indirect effect test is conducted to determine the effect of independent variable that influence dependent variable through intervening variables. Indirect effect can be shown through standardized indirect effect. Based on the results of the analysis of the indirect effect test in table 5 , it can be seen that the relationship of service quality to customer loyalty by customer trust and customer satisfaction to customer loyalty by customer trust is not significant because the $\mathrm{t}$ value is $<1.96$.

\section{DISCUSSION}

\section{The Effect of Service Quality on Customer Trust}

The service quality affect customer trust. This is indicating that customer will feel Merak Port is reliable and can be trusted if Merak Port can offer a good quality of service. Merak Port has to providing a good tangible aspect for customer, providing services as promises, providing a prompt service to customer, providing safe services, understand customer needs and giving individual attention to customer, this will be build customer trust in Merak Port ability, goodness and integrity. The results also shows service quality is the most important factor influencing customer trust. 
These findings are in line with the previous studies by (Boonlertvanich, 2019; Omoregie et al., 2019; P Kresnamurti Rivai et al., 2020; Rizan et al., 2016) that mention the importance of the service quality to gain customer trust.

\section{The Effect of Service Quality on Customer Loyalty}

The result shows that service quality of Merak Port does not have a significant effect on customer loyalty of Merak Port. PT ASDP Indonesia Ferry has to evaluate what problems occur in the service quality of Merak Port. The reason why customer keep using Merak Port can be due to respondents in this study will continue to using Merak Port service, because there are no other options, even though Merak Port cannot deliver a good quality of service and they are more searching for a value than a good quality of service.

This finding is in line with the previous study by (Abror et al., 2020; Fachmi et al., 2020; Rizan et al., 2016; Solimun \& Fernandes, 2018), which state that service quality does not have a significant effect on customer loyalty. However, it is different from the research conducted by Chang \& Thai (2016) which showed that service quality is the most important dimension that significantly impact customer loyalty.

\section{The Effect of Customer Satisfaction on Customer Trust}

Customer satisfaction has a significant effect on customer trust. This is indicating that the accumulation of satisfaction from several consumption experience can make customers of Merak Port trust the Merak Port easily in the future. Moreover, in order to gain customer trust, Merak Port has to providing a good service and happy experience for customer.

This finding is in line with the previous study by (Boonlertvanich, 2019; Hung et al., 2019; Melián-Alzola \& Martín-Santana, 2020) which state that if the customer feel satisfied with the service, it will reduce the uncertainty felt by customer to service provided as pointed by Morrison and Firmstone (2000) the main goal of trust is to reduce the uncertainty by better managing risk and simplifying the process of choice (Melián-Alzola \& Martín-Santana, 2020).

\section{The Effect of Customer Satisfaction on Customer Loyalty}

Customer satisfaction has a significant effect on customer trust. Customer satisfaction is a strong predictor of customer loyalty in the context of Merak Port. Satisfaction happen when the service given is more than their expectation then this is indicating that if customer of Merak Port already had a satisfactory experience with the Merak Port, they are willing to establish a long term relationship with Merak Port and they are inclined to come back again to get the service.

The result of these study by (Boonlertvanich, 2019; Haron et al., 2020; Ing et al., 2019; Omoregie et al., 2019) that signal the importance of customer satisfaction to achieve customer loyalty. This shows that 
when customer feel satisfied with their experience with Merak Port, they tend to be loyal.

\section{The Effect of Trust on Customer Loyalty}

The result shows that trust does not have a significant effect on customer loyalty of Merak Port. This can be due to customer seem to be less concerned with the capabilities of Merak Port, and also Merak Port has been known by the public. PT ASDP Indonesia Ferry has to evaluate what problems occur at Merak Port, so that the level of trust is low. This finding is supported with research conducted by Haron et al. (2020) and Ismanova (2019) which state that trust does not have a significant effect on customer loyalty. However, this finding is not in line with theory by Kanuk and Schiffman (2010) which say trust is the basis to maintaining long-term relationship with customer.

\section{The Effect of Service Quality on Customer Loyalty through Trust}

Service quality does not have a significant effect on loyalty through trust. This is indicating that in this study there is no mediating effect of trust in the relationship between service quality and customer loyalty, but the indirect effect between service quality and customer loyalty is stronger than the direct effect. This also indicates that customer trust in the reliability and integrity of Merak Port is not significant in mediating the effect of service quality on customer loyalty. This finding is supported by previous study by (Elizar et al., 2020; Ismanova, 2019; Wahyoedi et al., 2021) which state that service quality does not have a significant effect on customer loyalty indirectly by trust. However, this study is different from the finding by Rizan et al. (2016) which shows the mediating effect of trust in the relationship between service quality and customer loyalty.

\section{The Effect of Customer Satisfaction on Customer Loyalty through Trust}

Customer Satisfaction does not have a significant effect on loyalty through trust. This is indicating that there is no mediating effect of trust in the relationship between service quality and customer loyalty. This is can be due to the direct effect of customer satisfaction already strong, and customer already had enough experience with the Merak Port services and feel satisfied, so they do not have to feel trust to using the services Merak Port again. This finding is in line with past research by Utami (2017), however it is different from the finding by (Aljumah et al., 2020; Rocio Carranza et al., 2018; Darmawan, 2018; Haron et al., 2020) which shows the mediating effect of trust in the relationship between satisfaction and customer loyalty.

\section{CONCLUSION}

This research is conducted with the aim to test and analyze the impact of service quality and customer satisfaction on customer loyalty by the trust as a mediator variable. The sample of this research was 200 respondents who have visited Merak Port at least two times in the past 
year and have visited Merak Port before and after 2019. The data analysis is using SPSS version 22 and LISREL 8.8. The result of this study shows that, the first hypothesis shows that service quality has a significant effect on customer trust. The second hypothesis shows that service quality does not have significant effect on customer loyalty. The third hypothesis shows that customer satisfaction has a significant effect on customer trust. The fourth hypothesis shows that customer satisfaction has significant effect on customer loyalty and the most important variable that gain customer loyalty. The fifth hypothesis shows that customer trust does not have significant effect on customer loyalty. The sixth hypothesis shows that trust does not significantly mediate the relationship between service quality and customer loyalty. The seventh hypothesis shows that trust does not significantly mediate the relationship between customer satisfaction and customer loyalty.

\section{RECOMMENDATION}

In order to increase customer loyalty, it is hoped that Merak Port will provide a comfortable waiting room for customer, as well as providing clear and precise information about the arrival time of the ship, and if there are problems, it is expected that Merak Port officers will provide information to customers. Merak Port officers need to increase their interest in helping customers, give personal attention to customers who have special needs, and improve hospitality. Merak Port have to improve its services both facilities and infrastructure at the port, certainty of waiting times for ships, friendliness and physical appearance of officers and customer service who are able to provide information and handle customer complaints. For the further study it is hoped that can increase the amount of samples, because in this study the number of samples used was only 200 respondents, which is certainly not enough to show the actual situation at Merak Port. It is hoped that further research can use variables other than those used by researchers such as corporate image (Asnawi et al., 2019; Darmawan, 2018; Lunarindiah, 2016), Price ( Sinaga et al. 2016; Wulandari et al., 2016; Setyowati, 2017) or security quality variable as an independent variable that can affect customer loyalty is in accordance with the research of Chang \& Thai (2016).

\section{REFERENCES}

M., Harsasi, M., \& Pujiastuti, S. L. (2017). Pengaruh Kualitas Pelayanan Terhadap Loyalitas Pelanggan Pada Toko Buku Online Universitas Tebuka. Jurnal Manajemen Indonesia, 16(3), 155. https://doi.org/10.25124/jmi.v16i3.332

Abror, A., Patrisia, D., Engriani, Y., Evanita, S., Yasri, Y., \& Dastgir, S. (2020). Service quality, religiosity, customer satisfaction, customer engagement and Islamic bank's customer loyalty. Journal of Islamic Marketing, 11(6), 1691-1705. https://doi.org/10.1108/JIMA-03-2019-0044 
Aljumah, A., Nuseir, M. T., \& Islam, A. (2020). Impacts of service quality, satisfaction and trust on the loyalty of foreign patients in Malaysian medical tourism. International Journal of Innovation, Creativity and Change, 11(2), 451-467.

Asnawi, A. A., Awang, Z., Afthanorhan, A., Mohamad, M., \& Karim, F. (2019). The influence of hospital image and service quality on patients' satisfaction and loyalty. Management Science Letters, 9(6), 911-920. https://doi.org/10.5267/j.msl.2019.2.011

Boonlertvanich, K. (2019). Service quality, satisfaction, trust, and loyalty: the moderating role of main-bank and wealth status. International Journal of Bank Marketing, 37(1), 278-302. https://doi.org/10.1108/IJBM-02-2018-0021

Carranza, Rocio, Diaz, E., \& Martin-Consuegra, D. (2018). The influence of quality on satisfaction and customer loyalty with an importance-performance map analysis: Exploring the mediating role of trust. Journal of Hospitality and Tourism, 9(3), 380-396. https://doi.org/10.1108/jhtt-09-2017-0104

Carranza, Rocío, Díaz, E., \& Martín-Consuegra, D. (2018). The influence of quality on satisfaction and customer loyalty with an importance-performance map analysis: Exploring the mediating role of trust. Journal of Hospitality and Tourism Technology, 9(3), 380-396. https://doi.org/10.1108/JHTT-09-2017-0104

Chang, C. H., \& Thai, V. V. (2016). Do port security quality and service quality influence customer satisfaction and loyalty? Maritime Policy and Management, 43(6), 720-736. https://doi.org/10.1080/03088839.2016.1151086

Darmawan, B. A. (2018). The loyalty of Muslim customers on the Indonesian Islamic banks: the role of corporate image, satisfaction, and trust. Jurnal Siasat Bisnis, 22(2), 132-143. https://doi.org/10.20885/jsb.vol22.iss2.art2

Elizar, C., Indrawati, R., \& Syah, T. Y. . (2020). Service Quality, Customer Satisfaction, Customer Trust , and Customer Loyalty in Service of Paediatric Polyclinic Over Private H Hospital of East Jakarta , Indonesia. Journal of Multidisciplinary Academic, 04(02), 105-111.

Fachmi, M., Modding, B., Kamase, J., \& Damis, H. (2020). The Mediating Role of Satisfaction: Life Insurance Customers' Perspective (Service Quality, Trust and Image Toward Loyalty). International Journal of Multicultural and Multireligious Understanding, 7(6), 156-176. https://doi.org/10.18415/ijmmu.v7i6.1745

Hair, J. F., Black, W. C., Babin, B. J., \& Anderson, R. E. (2013). Multivariate Data Analysis. In Pearson New International Edition (7th ed.). Pearson. 
Hamonangan Sinaga, C., Sudiarta, I. N., \& Sasrawan Mananda, I. G. (2016). Pengaruh Harga Dan Kualitas Pelayanan Terhadap Loyalitas Melalui Kepuasan Wisatawan Nusantara Pada Maskapai Lion Air Di Bali. Jurnal IPTA, 4(2), 26. https://doi.org/10.24843/ipta.2016.v04.i02.p06

Haron, R., Subar, N. A., \& Ibrahim, K. (2020). Service quality of Islamic banks: satisfaction, loyalty and the mediating role of trust. Islamic Economic Studies, 28(1), 3-23. https://doi.org/10.1108/IES-12-2019-0041

Haryanti, S, S dan Susila, L,N. (2019). PENGARUH SERVICE QUALITY TERHADAP CUSTOMER LOYALTY DENGAN CUSTOMER SATISFACTION SEBAGAI VARIABEL MEDIASI ( Studi Kasus di Pasar Tradisional Bekonang Sukoharjo ) INFLUENCE of QUALITY SERVICE AND MARKETING RELASIONAL TO SATISFACTION AND LOYALITAS of CLIENT. 3(1), 1.

Haryono, S. (2016). Metode SEM Untuk Penelitian Manajemen dengan AMOS 22.00, LISREL 8.80 dan Smart PLS 3.0 (Vol. 1). PT. Intermedia Personalia Utama.

Hung, S. W., Cheng, M. J., \& Chiu, P. C. (2019). Do antecedents of trust and satisfaction promote consumer loyalty in physical and virtual stores? a multi-channel view. Service Business, 13(1). https://doi.org/10.1007/s11628-018-0364-y

Ing, P. G., Zheng Lin, N., Xu, M., \& Thurasamy, R. (2019). Customer loyalty in Sabah full service restaurant. Asia Pacific Journal of Marketing and Logistics, 32(7), 1407-1429. https://doi.org/10.1108/APJML-07-2019-0437

Intari, D. E., Kuncoro, H. B. B., \& Saputri, A. E. (2019). Evaluasi Kinerja Antrian Pada Loket Penumpang Pelabuhan Merak Banten. Jurnal Fondasi, 8(2), 176-185. http://jurnal.untirta.ac.id/index.php/jft/article/view/6665

Isaeva, N., Gruenewald, K., \& Saunders, M. N. K. (2020). Trust theory and customer services research: theoretical review and synthesis. Service Industries Journal, 40(15-16), 1031-1063. https://doi.org/10.1080/02642069.2020.1779225

Ismanova, D. (2019). Students' loyalty in higher education: The mediating effect of satisfaction, trust, commitment on student loyalty to Alma Mater. Management Science Letters, 9(8), 1161-1168. https://doi.org/10.5267/j.msl.2019.4.024

Kotler, P., \& Keller, K. L. (2016). Marketing Management Global Edition https://doi.org/10.1080/08911760903022556 
Lisa Wulandari, N. L., Kusuma Negara, I. M., \& Leli Kusuma Dewi, L. G. (2016). Pengaruh Kepuasan, Kepercayaan Dan Harga Terhadap Loyalitas Wisatawan Pengguna Layanan Booking.Com. Jurnal IPTA, 4(2), 88. https://doi.org/10.24843/ipta.2016.v04.i02.p18

Lunarindiah, G. (2016). THE INFLUENCE OF CORPORATE IMAGE, SERVICE QUALITY, PERCEIVED VALUE TOWARD STUDENT SATISFACTION AND STUDENT LOYALTY. 9(2), 239-252.

Malhotra, N. K. (2010). [ISBN 978-0-13-608543-0] Naresh K. Malhotra - Marketing Research-An Applied Orientation (0).pdf.

Melián-Alzola, L., \& Martín-Santana, J. D. (2020). Service quality in blood donation: satisfaction, trust and loyalty. Service Business, 14(1), 101-129. https://doi.org/10.1007/s11628-019-00411-7

Omoregie, O. K., Addae, J. A., Coffie, S., Ampong, G. O. A., \& Ofori, K. S. (2019). Factors influencing consumer loyalty: evidence from the Ghanaian retail banking industry. International Journal of Bank Marketing, 37(3), 798-820. https://doi.org/10.1108/IJBM-04-2018-0099

P Kresnamurti Rivai, A., Hady, H., Limakrisna, N., Nabiilurrahman, \& Zyadzya, H. (2020). Investigation of Customer Trust and Customer Loyalty on Transjakarta's Bus. Talent Development \& Excellence, 12(1), 92-99. http://search.ebscohost.com/login.aspx?direct=true $\& \mathrm{db}=\mathrm{s} 3 \mathrm{~h} \&$ $\underline{\mathrm{AN}=143468454 \& \text { lang }=\mathrm{ja} \& \text { site }=\text { ehost-live }}$

Prabumenang, A. K. R., Wibowo, A., Narmaditya, B. S., \& Prihandono, D. (2020). Determinant factors of fuel consumption behavior: Evidence from Indonesia. Utopia y Praxis Latinoamericana, 25(Extra 7), 144-155. https://doi.org/10.5281/zenodo.4009624

Rizan, M., Setyaningsih, R., \& Saidani, B. (2016). the Influence of Service Quality and Price Toward Trust and Its Impact on Customer Loyalty of Low Cost Carrier Indonesia. JRMSI Jurnal Riset Manajemen Sains Indonesia, 7(1), 176-196. https://doi.org/10.21009/jrmsi.007.1.10

Saputra, A., Alwie, A. F., \& Widayatsari, A. (2020). Pengaruh Promosi Dan Kualitas Pelayanan Terhadap Kepercayaan Dan Loyalitas Donatur Dompet Dhuafa Riau. Jurnal Dakwah Risalah, 31(1), 70. https://doi.org/10.24014/jdr.v31i1.10040

Servera-francés, D., Piqueras-tomás, L., \& Servera-franc, D. (2019). The effects of corporate social responsibility on consumer loyalty through consumer perceived value loyalty through consumer perceived value. Economic Research-Ekonomska 
Istraživanja,

$32(1)$,

$66-84$. https://doi.org/10.1080/1331677X.2018.1547202

Setyowati, E. (2017). Pengaruh Kualitas Pelayanan, Harga, Dan Citra Merek Terhadap Loyalitas Pelanggan Dengan Kepuasan Pelanggan Sebagai Variabel Pemediasi. Jurnal Manajemen Dayasaing, $18(2)$,

102. https://doi.org/10.23917/dayasaing.v18i2.4507

Solimun, S., \& Fernandes, A. A. R. (2018). The mediation effect of customer satisfaction in the relationship between service quality, service orientation, and marketing mix strategy to customer loyalty. Journal of Management Development, 37(1), 76-87.

Sugiyono. (2019). Metode Penelitian Kuantitatif, Kualitas dan R\&D (1st ed.). ALFABETA.

Toiskandar. (2020, October 18). Nenek di Cilegon Tewas Tergencet Kapal Ferry, Polisi Periksa Operator Jembatan. https://regional.inews.id/berita/nenek-di-cilegon-tewastergencet-kapal-ferry-polisi-periksa-operator-jembatan/2

Utami, W. (2017). Pengaruh Kualitas Layanan Elektronik pada Loyalitas Elektronik (Kepuasan Eelektronik sebagai Variabel Mediasi dan Kepercayaan yang Dirasakan sebagai Variabel Moderasi ). Menara Ekonomi, III(6), 20-32.

Wahyoedi, S., Sudiro, A., Sunaryo, S., \& Sudjatno, S. (2021). The effect of religiosity and service quality on customer loyalty of Islamic banks mediated by customer trust and satisfaction. Management Science Letters, 11, 187-194. https://doi.org/10.5267/j.msl.2020.8.016

Yacob, Y., Ali, J. K., Baptist, C. J., Nadzir, H. M., \& Morshidi, M. H. (2016). How Far Members' Satisfaction Mediated Members' Loyalty? Investigating Credit Cooperative in Sarawak Borneo. Procedia - Social and Behavioral Sciences, 224(August 2015), 376-383. https://doi.org/10.1016/j.sbspro.2016.05.391

Yandhi. (2020). Antrean Penumpang Sempat Mengular Di Pelabuhan Merak. www.Cnnindonesia.com/nasional/20201224144717-20586049/antrean-penumpang-sempat-mengular-di-pelabuhanmerak. 